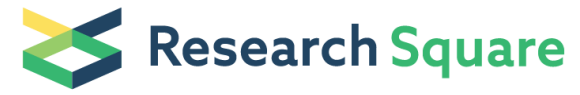 \\ Preprints are preliminary reports that have not undergone peer review. \\ They should not be considered conclusive, used to inform clinical practice, \\ or referenced by the media as validated information.
}

\section{Cardiac involvement in eosinophilic granulomatosis with polyangitis: a retrospective study in Chinese population}

\section{Yingying Chen}

Department of Rheumatology, Peking Union Medical College Hospital, Beijing, China Jiaxin Zhou

Department of Rheumatology, Peking Union Medical College Hospital, Beijing, China

Jing Li

Department of Rheumatology, Peking Union Medical College Hospital, Beijing, China

Qingjun Wu

Department of Rheumatology, Peking Union Medical College Hospital, Beijing, China

\section{Hongxian Yang}

Department of Nephrology, Children's Hospital affiliated to Capital Institute of Pediatrics, Bejing 100020,

China

\section{Shangzhu Zhang}

Department of Rheumatology, Peking Union Medical College Hospital, Beijing, China

\section{Yunyun Fei ( $\nabla$ feiyunyun2013@hotmail.com )}

Peking Union Medical Cellege Hospital, Chinese Academy of Medical Science \& Peking Union Medical College https://orcid.org/0000-0003-1728-2342

\section{Wen Zhang}

Department of Rheumatology, Peking Union Medical College Hospital, Beijing, China

\section{Yan Zhao}

Department of Rheumatology, Peking Union Medical College Hospital, Beijing, China

\section{Fengchun Zhang}

Department of Rheumatology, Peking Union Medical College Hospital, Beijing, China

\section{Xiaofeng Zeng}

Department of Rheumatology, Peking Union Medical College Hospital, Beijing, China

\section{Research article}

Keywords: Eosinophilic granulomatosis with polyangitis, cardiac involvement, clinical characteristics, outcome

Posted Date: May 11th, 2020

DOI: https://doi.org/10.21203/rs.3.rs-27166/v1 
License: (9) (1) This work is licensed under a Creative Commons Attribution 4.0 International License. Read Full License 


\section{Abstract}

Background: Cardiac involvement in EGPA indicates poor prognosis and high mortality, while few data about cardiac involvement of EGPA in Chinese population are available. We conducted this study to figure out the clinical characteristics and overall outcome of EGPA patients with cardiac involvement in Chinese population.

Methods: We retrospectively collected the clinical data of 83 patients diagnosed with EGPA and analyzed the differences between patients with and without cardiac involvement.

Results: The prevalence of cardiac involvement of EGPA in this cohort was $27.7 \%$. Compared with those who without cardiac involvement, EGPA patients with cardiac involvement tended to have younger onset age (mean $\pm \mathrm{SD}, 38.4 \pm 10.5$ vs. $42.1 \pm 15.9$ years, $p=0.039$ ), higher eosinophil count [median (IQR), 5810 (4020-11090) vs. 2880 (1530-6570) $n / \mu \mathrm{L}, \mathrm{p}=0.004)$ ], higher disease activity [median (IQR), 20 (16-28) vs. 15 (12-18), p=0.001)] and poorer prognosis ( $F F S \geq 1,100 \%$ vs. $38.3 \%, p=0.001)$. The most common cardiac manifestation was chest pain $(56.5 \%)$, and $43.5 \%$ of patients were asymptomatic but cardiac abnormalities could be detected by cardiac examinations. With appropriate treatment, the overall outcome of EGPA patients with cardiac involvement in our cohort turned out to be good, with $3(13 \%)$ patients died at acute phase and no patient died during follow-up.

Conclusions: Cardiac involvement was common in EGPA and was associated with younger onset age, higher eosinophil count, higher disease activity and poorer prognosis. Comprehensive cardiac examinations and appropriate treatment are essential to improve the prognosis of cardiac involvement.

\section{Background}

Eosinophilic granulomatosis with polyangitis (EGPA), formerly known as Churg-Strauss syndrome (CSS), was first described by Churg and Strauss as a rare autoimmune disease characterized by severe asthma, hypereosinophilia and symptoms of necrotizing vasculitis in various organs[1]. It is classified as an antineutrophil cytoplasmic antibody (ANCA)-associated systemic vasculitis affecting small to medium-size vessels[2], with ANCA positivity ranging from $26.2 \% \sim 85 \%$ [3-9].

As a common target organ, cardiac involvement has been reported in $16.1 \%$ 92\% of EGPA patients according to previous studies[1, 4, 9-16]. The cardiac manifestations of EGPA are diverse, ranging from myocarditis, arrhythmia, valvular defects, heart failure, myocardial infarction and pericardial effusion to cardiac tamponade[11, 13, 16-18]. Cardiac involvement in EGPA strongly predicts worse prognosis[5, 19] and higher mortality [5, 14, 20-22]. So far, there has been few data available on cardiac involvement in EGPA patients in Chinese population. We retrospectively studied the data of 83 Chinese EGPA patients to describe and analyze the prevalence, clinical characteristics, prognostic factors and outcome of cardiac involvement in EGPA patients in China, aiming to strengthen people's understanding of cardiac involvement in EGPA and provide some meaningful information for physicians during clinical practice.

\section{Methods}

\section{Patients}


We retrospectively collected the data of patients diagnosed with EGPA and hospitalized in Peking Union Medical College Hospital from December 2001 to June 2018 by retrieving medical records. All patients fulfilled the American College of Rheumatology criteria for EGPA[23]. Briefly, patients who met four or more of the following diagnostic criteria would be diagnosed with EGPA: (1) asthma; (2) eosinophilia囚10\%; (3) mononeuropathy or polyneuropathy; (4) non-fixed pulmonary infiltrates; (5) paranasal sinus abnormality; (6) extravascular eosinophils. Birmingham vasculitis activity score (BVAS)[24] was used to assess disease activity and the revisited Five Factor Score (FFS)[20] to evaluate the prognosis of all EGPA patients included in this study.

According to previous studies[14, 17, 25], cardiac manifestations were attributable to EGPA when patients presented with significant arrhythmia, pericardial effusion, acute heart failure, regional or global wall motion abnormalities, diastolic dysfunction, cardiomyopathy, vavular dysfunction and myocardial enzyme abnormalities which couldn't be explained by other etiologies.

\section{Clinical data}

All the clinical data including age at disease onset, disease duration, initial symptoms, organ involvement, hospitalization time, clinical manifestations, laboratory findings, imaging examinations, treatment and follow up were recorded. Laboratory findings at diagnosis and after treatment were recorded retrospectively, such as complete blood count, serum immunoglobulin E (IgE) levels, hypersensitive C-reactive protein (hsCRP), erythrocyte sedimentation rate (ESR), ANCA test, myocardial enzyme levels, N-terminal prohormone of brain natriuretic peptide (NT-proBNP), liver function test, serum creatinine and so on. Imaging examinations included electrocardiogram (ECG), 24 hours dynamic electrocardiogram (DCG), ultrasound scan, magnetic resonance imaging (MRI), computed tomography (CT) scan, neuroelectrophysiological examination etc. Plus, some patients underwent lung/skin/renal/heart biopsy upon indication and the pathology results were also recorded.

\section{Statistical analysis}

Continuous variables were shown as mean \pm standard deviation (SD) or median (interquartile range, IQR), while categorical variables were shown as numbers (percentage). Continuous variables were analyzed using Student's t test or Mann-Whitney Utest, and categorical variables used chi-square test or Fisher's exact test as required. Type-1 error was decided to be 5\%. Statistics were analyzed via a SPSS version 23.0 software.

\section{Results}

\section{Demographic data and clinical manifestations}

Eighty-three EGPA patients (mean \pm SD age $47.3 \pm 14.3$ years) were included in this study, among which there were 57 (68.7\%) men and 26 (31.3\%) women. Twenty-three $\ 27.7 \%$ patients were diagnosed with cardiac involvement in this cohort. The median duration before diagnosis was 36 months (IQR, 12-84). Sixty-four $(77.1 \%)$ patients had asthma, $67(80.7 \%)$ patients had paranasal sinus abnormalities and non-fixed pulmonary infiltrates were observed in 72 (86.7\%) patients. Additionally, 19 (22.9\%) patients were diagnosed with renal involvement and 18 (21.7\%) patients with gastrointestinal involvement. Fourteen (16.9\%) patients had central nervous system involved, while 57 (68.7\%) patients had the manifestations of peripheral neuropathy. 
As for laboratory findings, all but 1 patient underwent ANCA test and ANCA positivity was found in 26 (31.7\%) patients, among which 4 (15.4\%) patients were cANCA positive and 22 (84.6\%) patients were pANCA positive. EGPA patients also had blood eosinophilia: median absolute eosinophil count, 4160/ $\mu \mathrm{L}$ (IQR, 1830-8780).

\section{Cardiac involvement}

In this study, 23 (27.7\%) patients were diagnosed with cardiac involvement, among which 13 (56.5\%) patients presented with chest pain and dyspnea and 10 (43.5\%) patients were asymptomatic. The diagnosis of cardiac involvement was made upon the combination of clinical symptoms, myocardial enzyme levels, ECG and cardiac imaging examinations. Three (13\%) patients were admitted to hospital due to cardiac involvement, while other patients were found to have cardiac involvement during hospitalization. Compared with EGPA patients without cardiac involvement, patients with cardiac involvement had younger onset age (mean \pm SD, $38.4 \pm 10.5$ vs. $42.1 \pm 15.9$ years, $p=0.039$ ). Furthermore, women were inclined to have cardiac involvement in this cohort, since there were 11 (47.8\%) women in the group of cardiac involvement, while there were only 15 $(25 \%)$ women in the group of non-cardiac involvement $(p=0.045)$. Patients with cardiac involvement tended to have higher eosinophil count [median (IQR), 5810 (4020-11090) vs. 2880 (1530-6570) n/ $\mu \mathrm{L}, \mathrm{p}=0.004$ ]. There were no differences between the two groups considering organ involvement and the level of hsCRP, ESR as well as serum IgE. These data are shown in Table 1 in detail.

All patients with cardiac involvement underwent ECG test: 4 (17.4\%) patients were found to have sinus tachycardia and $5(21.7 \%)$ have ST-segment or T wave abnormalities. Among them, one (4.3\%) patient who had ST-segment elevation and progressed to cardiac arrest survived due to timely cardio-pulmonary resuscitation. One (4.3\%) patient was found to have third-degree atrioventricular block and needed the support of temporary pacemaker. Ten (43.5\%) patients did not present with ECG abnormalities, but had elevated myocardial enzymes or echocardiographic changes. Thirteen patients (56.5\%) had elevated cardiac Troponin I (cTn I) levels and elevated NT-proBNP levels were found in 12 patients (52.2\%).

Echocardiography was performed in all patients with cardiac involvement, and 21 (95.5\%) patients had different kinds of cardiac disorders. Six (26.1\%) patients were found to have decreased LVEF [median (IQR), $34.1 \%$ (31\%-46\%)], among which one patient needed extracorporeal membrane oxygenation (ECMO) support because of cardiogenic shock caused by extremely low LVEF (11\%). Eleven (47.8\%) patients had diastolic function abnormality or segmental dyskinesia, and 6 (26.1\%) patients had mitral or tricuspid insufficiency. Mild to moderate pericardial effusion was observed in 7 (30.4\%) patients. Only 2 (8.7\%) patients underwent cardiac MRI examination, and both were found to have late gadolinium enhancement of the myocardium and one had decreased LVEF (43.8\%) which was not identified by the echocardiography. Six patients had coronary artery CTA examination, none of which had major abnormalities that can account for cardiac involvement. These findings can be seen in Table 2 .

\section{Disease activity, treatment, outcome and follow-up}

In contrast with patients without cardiac involvement, patients with cardiac involvement had higher BVAS [median (IQR), 20 (16-28) vs. 15 (12-18), p=0.001], which indicated higher disease activity in the group of the cardiac involvement. Moreover, patients with cardiac involvement had more chance to have poor prognosis (FFS $\geq 1,100 \%$ vs. $38.3 \%, p=0.001$ ). 
All patients with cardiac involvement accepted the combination of glucocorticoids and cyclophosphamide (CTX) as induction treatment. Fifteen (65.2\%) patients were given methylprednisolone pulse plus CTX therapy, $8(34.8 \%)$ patients received the treament of high dose glucocorticoids plus CTX. Maintenance treatment included glucocorticoids plus CTX $(n=18)$ and glucocorticoids alone $(n=2)$.

As for the outcome of EGPA patients with cardiac involvement, one patient died of infectious shock due to gut perforation, one patient died of multi-organ failure and one died of cerebral hernia. Twenty (87\%) patients achieved remission after treatment, with LVEF improved, myocardial enzymes decreased or ECG become normal.

The median follow-up period of patients with cardiac involvement was 38 months (IQR, 25-69.5), with one patient lost to follow up. During the follow up, $3(15.8 \%)$ patients relapsed and were admitted into the hospital again. The relapsed organs were heart, ear and lung respectively, and all patients achieved remission again after treatment. No relationship was observed between the the presence of relapse and disease activity as described by BVAS or FFS at baseline. One (5.3\%) patient progressed to heart failure, 15 (78.9\%) patients achieved long term remission and no patients died during follow up. These findings are shown in Table 3 .

Table 1. Characteristics of EGPA patients with or without cardiac involvement 
Cardiac Involvement Non-Cardiac involvement $\quad \mathrm{p}$ Value $(n=23) \quad(n=60)$

\begin{tabular}{|c|c|c|c|}
\hline Female & $11(47.8 \%)$ & $15(25 \%)$ & 0.045 \\
\hline Age at onset (yr) & $38.4 \pm 10.5$ & $42.1 \pm 15.9$ & 0.039 \\
\hline Duration (m) & $36(24-72)$ & $30(12-96)$ & 0.959 \\
\hline Hospitalization time (d) & $28(20-39)$ & $25(20-32.8)$ & 0.404 \\
\hline Follow up (m) & $38(25-69.5)$ & $34.5(14.3-58.5)$ & 0.492 \\
\hline \multicolumn{4}{|l|}{ Clinical features } \\
\hline Skin involvement & $10(43.5 \%)$ & 37 (61.7\%) & 0.135 \\
\hline ENT involvement & $18(78.3 \%)$ & $49(81.7 \%)$ & 0.760 \\
\hline Asthma & $18(78.3 \%)$ & $46(76.7 \%)$ & 0.877 \\
\hline Lung infiltration & $20(87 \%)$ & $52(86.7 \%)$ & 1 \\
\hline Renal involvement & $4(17.4 \%)$ & $15(25 \%)$ & 0.460 \\
\hline GI involvement & $6(26.1 \%)$ & $12(20 \%)$ & 0.562 \\
\hline Peripheral neuropathy & $16(69.6 \%)$ & $41(68.3 \%)$ & 0.914 \\
\hline CNS manifestation & $4(17.4 \%)$ & $10(16.7 \%)$ & 1 \\
\hline BVAS & $20(16-28)$ & $15(12-18)$ & 0.001 \\
\hline \multicolumn{4}{|l|}{ FFS } \\
\hline 0 & $0(0 \%)$ & $37(61.7 \%)$ & \\
\hline 1 & $14(60.9 \%)$ & $18(30 \%)$ & 0.001 \\
\hline 2 & $9(39.1 \%)$ & $5(8.3 \%)$ & \\
\hline ANCA positivity & $5(21.7 \%)$ & $21(35 \%)$ & 0.226 \\
\hline Eosinophil count $(\mathrm{n} / \mu \mathrm{L})$ & $5810(4020-11090)$ & $2880(1530-6570)$ & 0.004 \\
\hline Eosinophil count (\%) & $42.7(32.3-56.7)$ & $33.3(20.1-46)$ & 0.02 \\
\hline $\operatorname{ESR}(\mathrm{mm} / \mathrm{h})$ & $30(9-75)$ & $40(17.5-58.5)$ & 0.962 \\
\hline hsCRP (mg/L) & $25.2(7.1-81.3)$ & $29.3(9.2-98.5)$ & 0.755 \\
\hline Serum IgE (kU/L) & 469 (212.5-1635) & 413.5 (162.5-1524.3) & 0.681 \\
\hline
\end{tabular}

Abbreviations: ENT: ears, nose, and throat; GI: gastrointestinal; CNS: central nervous system; BVAS:

Birmingham vasculitis activity score; FFS: Five Factor Score; ANCA: antineutrophil cytoplasmic antibody; ESR: erythrocyte sedimentation rate; hsCRP: hypersensitive C-reactive protein; IgE: immunoglobulin $\mathrm{E}$. 
Table 2. Cardiac findings in 23 patients with EGPA 


\begin{tabular}{|c|c|c|c|c|c|c|c|}
\hline Case & Age/sex & cTn I & $\begin{array}{l}\text { NT- } \\
\text { proBNP }\end{array}$ & ECG & CTA & Echocardiography & Cardiac MRI \\
\hline 1 & $40 / F$ & NA & NA & $\begin{array}{l}\text { sinus } \\
\text { tachycardia }\end{array}$ & NA & LVEF $37.2 \%$ & NA \\
\hline 2 & $34 / \mathrm{M}$ & elevated & elevated & $\begin{array}{l}\text { left anterior } \\
\text { hemiblock }\end{array}$ & normal & $\begin{array}{l}\text { LVEF } 46 \% \text {, } \\
\text { diastolic function } \\
\text { abnormality }\end{array}$ & NA \\
\hline 3 & $39 / F$ & elevated & elevated & $\begin{array}{l}\text { sinus } \\
\text { tachycardia }\end{array}$ & normal & normal & NA \\
\hline 4 & $37 / M$ & normal & normal & $\begin{array}{l}\text { ST-segment } \\
\text { elevation }\end{array}$ & $\begin{array}{l}25 \% \\
\text { stenosis } \\
\text { of LAD }\end{array}$ & $\begin{array}{l}\text { LVEF } 46 \% \text {, } \\
\text { segmental } \\
\text { dyskinesia }\end{array}$ & NA \\
\hline 5 & $49 / \mathrm{M}$ & normal & NA & normal & NA & $\begin{array}{l}\text { echo- } \\
\text { enhancement of } \\
\text { myocardium, } \\
\text { hypokinesia }\end{array}$ & NA \\
\hline 6 & $25 / \mathrm{M}$ & NA & NA & normal & NA & $\begin{array}{l}\text { pericardial } \\
\text { effusion }\end{array}$ & NA \\
\hline 7 & $49 / F$ & elevated & elevated & $\begin{array}{l}\text { AVB grade } \\
\text { III }\end{array}$ & NA & $\begin{array}{l}\text { LVEF } 31 \% \text {, } \\
\text { diastolic function } \\
\text { abnormality }\end{array}$ & NA \\
\hline 8 & $36 / F$ & elevated & NA & PVC & NA & $\begin{array}{l}\text { LVEF } 31 \% \rightarrow 11 \% \text {, } \\
\text { mitral } \\
\text { insufficiency }\end{array}$ & NA \\
\hline 9 & $49 / F$ & elevated & elevated & normal & Normal & $\begin{array}{l}\text { pericardial } \\
\text { effusion, mitral } \\
\text { and tricuspid } \\
\text { insufficiency }\end{array}$ & NA \\
\hline 10 & $34 / F$ & elevated & NA & normal & NA & normal & NA \\
\hline 11 & $30 / F$ & elevated & elevated & normal & NA & $\begin{array}{l}\text { mild mitral } \\
\text { insufficiency }\end{array}$ & NA \\
\hline 12 & $42 / F$ & elevated & elevated & normal & normal & $\begin{array}{l}\text { myocardiopathy, } \\
\text { hypokinesia }\end{array}$ & NA \\
\hline 13 & $48 / \mathrm{M}$ & normal & normal & normal & NA & $\begin{array}{l}\text { echo- } \\
\text { enhancemen of } \\
\text { left ventricular } \\
\text { apex, hypokinesia }\end{array}$ & NA \\
\hline 14 & $26 / M$ & elevated & elevated & $\begin{array}{l}\text { V1-6 ST- } \\
\text { segment } \\
\text { depression }\end{array}$ & NA & $\begin{array}{l}\text { LVEF } 31 \% \text {, mitral } \\
\text { insufficiency, } \\
\text { hypokinesia, mild } \\
\text { PAH }\end{array}$ & NA \\
\hline 15 & $57 / M$ & normal & elevated & PVC, SVT & NA & $\begin{array}{l}\text { LVEF 68\%, } \\
\text { hypokinesia, } \\
\text { mild pericardial } \\
\text { effusion }\end{array}$ & NA \\
\hline
\end{tabular}




\begin{tabular}{|c|c|c|c|c|c|c|c|}
\hline 16 & $54 / F$ & elevated & elevated & normal & NA & $\begin{array}{l}\text { pericardial } \\
\text { effusion }\end{array}$ & NA \\
\hline 17 & $28 / M$ & normal & normal & normal & NA & $\begin{array}{l}\text { LVEF 63\%, } \\
\text { segmental } \\
\text { dyskinesia }\end{array}$ & $\begin{array}{l}\text { LGE of } \\
\text { interventricular } \\
\text { septum }\end{array}$ \\
\hline 18 & $34 / \mathrm{M}$ & normal & elevated & $\begin{array}{l}\text { Sinus } \\
\text { tachycardia }\end{array}$ & NA & $\begin{array}{l}\text { LVEF } 50 \% \text {, } \\
\text { hypokinesia, mild } \\
\text { pericardial } \\
\text { effusion }\end{array}$ & NA \\
\hline 19 & $31 / \mathrm{F}$ & normal & normal & $\begin{array}{l}\text { Sinus } \\
\text { tachycardia, } \\
\text { IIIIIIIIaVF } \\
\text { V4-6 ST- } \\
\text { segment } \\
\text { depression }\end{array}$ & NA & $\begin{array}{l}\text { LVEF 73\%囚diffuse } \\
\text { thickening of } \\
\text { pericardium, mild } \\
\text { pericardial } \\
\text { effusion }\end{array}$ & NA \\
\hline 20 & $55 / F$ & elevated & elevated & $\begin{array}{l}\mathrm{V} 1-5 \mathrm{~T} \\
\text { wave } \\
\text { inversion }\end{array}$ & NA & $\begin{array}{l}\text { LVEF } 62 \% \text {, mild } \\
\text { pericardial } \\
\text { effusion }\end{array}$ & NA \\
\hline 21 & $57 / \mathrm{M}$ & normal & normal & P mitrale & NA & $\begin{array}{l}\text { mitral } \\
\text { insufficiency, mild } \\
\text { PAH }\end{array}$ & NA \\
\hline 22 & $53 / \mathrm{M}$ & elevated & elevated & normal & normal & $\begin{array}{l}\text { LVEF 62\%, } \\
\text { segmental } \\
\text { dyskinesia }\end{array}$ & $\begin{array}{l}\text { LGE of left and } \\
\text { right } \\
\text { ventricular } \\
\text { wall, } \\
\text { LVEF }=43.8 \% \text {, } \\
\text { mild } \\
\text { pericardial } \\
\text { effusion }\end{array}$ \\
\hline 23 & $53 / \mathrm{M}$ & elevated & NA & $\begin{array}{l}\text { V4-6 ST- } \\
\text { segment } \\
\text { depression }\end{array}$ & NA & $\begin{array}{l}\text { left ventricular } \\
\text { hypertrophy, } \\
\text { mitral } \\
\text { insufficiency }\end{array}$ & NA \\
\hline
\end{tabular}

Abbreviations: cTn I: cardiac Troponin I; NT-proBNP: N-terminal prohormone of brain natriuretic peptide; ECG: electrocardiogram; CTA: computed tomography angiography; MRI: magnetic resonance imaging; LAD: left anterior descending; AVB: atrioventricular block; LVEF: left ventricular ejection fraction; PAH: pulmonary artery hypertension; PVC: premature ventricular contraction; SVT: supraventricular tachycardia; LGE: late gadolinium enhancement; NA: not available.

Table 3. Treatment, outcome and follow-up of 23 patients with EGPA 


\begin{tabular}{|c|c|c|c|c|c|c|}
\hline Case & BVAS & FFS & Induction treatment & Maintenance treatment & Outcome & Follow-up \\
\hline 1 & 34 & 2 & MP pulse/CTX & - & death & - \\
\hline 2 & 15 & 1 & MP pulse/CTX & MP & remission & remission \\
\hline 3 & 16 & 1 & MP pulse/CTX & Pred/CTX & remission & relapse \\
\hline 4 & 13 & 2 & MP/CTX & Pred/CTX & remission & relapse \\
\hline 5 & 29 & 2 & MP pulse/СTX & MP/CTX & remission & remission \\
\hline 6 & 16 & 1 & Pred/CTX & Pred & remission & lost \\
\hline 7 & 24 & 1 & MP/CTX & MP/CTX & remission & remission \\
\hline 8 & 18 & 2 & MP pulse/CTX & Pred/CTX & remission & remission \\
\hline 9 & 20 & 1 & MP/CTX & MP/CTX & remission & remission \\
\hline 10 & 19 & 2 & MP/CTX & Pred/CTX & remission & remission \\
\hline 11 & 14 & 1 & MP pulse/CTX & Pred/CTX & remission & remission \\
\hline 12 & 21 & 1 & MP pulse/CTX & Pred/CTX & remission & $\mathrm{CHF}$ \\
\hline 13 & 24 & 1 & MP/CTX & MP/CTX & remission & remission \\
\hline 14 & 38 & 2 & MP pulse/CTX & - & death & - \\
\hline 15 & 19 & 1 & MP pulse/CTX & Pred/CTX & remission & remission \\
\hline 16 & 33 & 2 & MP pulse/CTX & - & death & - \\
\hline 17 & 20 & 1 & Pred/CTX & Pred/CTX & remission & remission \\
\hline 18 & 42 & 2 & MP/CTX & Pred/CTX & remission & remission \\
\hline 19 & 12 & 1 & MP/CTX & Pred/CTX & remission & relapse \\
\hline 20 & 18 & 1 & MP/CTX & Pred/CTX & remission & remission \\
\hline 21 & 16 & 1 & MP pulse/CTX & MP/CTX & remission & remission \\
\hline 22 & 23 & 1 & MP pulse/CTX & MP/CTX & remission & remission \\
\hline 23 & 28 & 2 & MP pulse/CTX & MP/CTX & remission & remission \\
\hline
\end{tabular}

Abbreviations: MP: methylprednisolone; Pred: prednisone; CTX: cyclophosphamide; CHF: chronic heart failure.

\section{Discussion}

EGPA was believed to have a better prognosis than other ANCA-associated vasculitis[5, 26], while cardiac involvement is an independent risk factor of mortality $[5,20]$. Previous studies have demonstrated the prevalence of cardiac involvement of EGPA ranging from 16.1\% 92\%, while the prevalence in our cohort was $27.7 \%$, which was relatively low. One reason may lie in the fact that only two patients underwent cardiac MRI which is more sensitive and can identify cardiac abnormalities in EGPA patients despite normal ECG and 
echocardiography as previous studies suggested $[9,14,27,28]$. Patients with cardiac involvement had distinct characteristics from those without cardiac involvement in this cohort. According to previous studies[11, 12, 17, 29], EGPA was more common in male than female, which was also observed in our cohort (male vs. female, $68.7 \%$ vs. $31.3 \%$ ). However, there were more female patients $(47.8 \%)$ in the group of cardiac involvement than that in the group of non-cardiac involvement (25\%), indicating that female patients have a higher incidence of cardiac involvement in this population. Furthermore, patients with cardiac involvement in our study tended to have younger onset age compared with those without cardiac involvement, which was not identified in other studies.

It was demonstrated by many studies that ANCA negativity was correlated with heart involvement and lung involvement $[4,6,19,25]$, while ANCA positivity was correlated with renal involvement and pulmonary hemorrhage $[4,6,30]$. Thus, cardiac involvement of EGPA was regarded as the result of eosinophilic infiltration in the tissue [1,31], and eosinophilia played a more significant role than ANCA in cardiac involvement of EGPA[15]. In our study, we also noted a higher level of eosinophil count in the group of cardiac involvement, which was consistent with the findings of previous series[15, 25]. Though not significant, the percentage of ANCA positivity was lower in the group of cardiac involvement in this study. A number of patients had taken glucocorticoids treatment before diagnosis, which may account for this phenomenon.

The diagnosis of cardiac involvement was made upon the combination of clinical manifestations, ECG, myocardial enzyme levels, coronary artery CTA, echocardiography and cardiac MRI. Chest pain was a common syndrome caused by cardiac involvement in our series, which is in accordance with the series of Vinit, J., et al. [15]. However, almost half of the patients were asymptomatic or had normal ECG, while there were cardiac abnormalities detected by echocardiography or cardiac MRI. As a result, an overall evaluation of heart condition should be taken to exclude cardiac involvement despite normal ECG and absence of cardiac manifestations, as recommended by previous studies[14, 17], since cardiac involvement in EGPA indicates poor prognosis and high mortality.

EGPA patients with cardiac involvement tended to have higher FFS as previously reported[9, 25], which was also noted in our cohort, suggesting a poor prognosis in patients with cardiac involvement. It was also identified in our study that patients with cardiac involvement had higher BVAS, which predicted higher disease activity and severe organ damage. However, the application of glucocorticoids and the combination of immunosuppressive agents such as CTX in severe cases significantly improved the outcome of EGPA[5, 19]. Thus, all patients with cardiac involvement in our study received the induction treatment of high dose glucocorticoids combined with CTX and achieved remission in acute phase. Consequently, the overall outcome of patients with cardiac involvement in our cohort turned out to be good. Therefore, early diagnosis and appropriate treatment are indispensable to prevent the acceleration of cardiac involvement in EGPA[17, 32, 33].

This is the first study with a relatively large sample concerning the cardiac involvement of EGPA patients in Chinese population according to our knowledge. We identify that patients with cardiac involvement have distinct clinical characteristics from those without cardiac involvement in this cohort, which may provide some meaningful information for physicians during clinical practice. What's more, our study also suggests that cardiac involvement predicts poor prognosis and higher disease activity in EGPA patients. Comprehensive 
cardiac examinations and appropriate treatment are essential to make early diagnosis and improve the outcome of cardiac involvement of EGPA patients in our study.

However, there are several limitations of our study. First of all, this is a cross-sectional and retrospective study that may bring in some biases, which may have an influence on the results. Lack of endomyocardial biopsy to confirm the diagnosis of cardiac involvement is another limitation of our study.

\section{Conclusion}

In conclusion, cardiac involvement was common in this EGPA cohort and mainly presented with chest pain. Compared with those without cardiac involvement, patients with cardiac involvement tended to have association with younger onset age, higher eosinophil count, higher disease activity and poorer prognosis. Comprehensive cardiac examinations are important to make early diagnosis. High-dose glucocorticoids combined with CTX might be the preferred treatment which can prevent the acceleration of cardiac involvement effectively.

\section{Declarations}

\section{Ethics approval and consent to participate}

The study was approved by the Ethics Committee of Peking Union Medical College Hospital. Written informed consent couldn't be obtained due to the retrospective nature of this study.

\section{Consent for publication}

Not applicable.

\section{Availability of data and materials}

The datasets used and/or analyzed during the current study are available from the corresponding author on reasonable request.

\section{Competing interests}

The authors declare that they have no competing interests.

\section{Funding}

This work was supported by the the National Natural Science Foundation of China (grant numbers 81671620 and 81971545) and CAMS Innovation Fund for Medical sciences (CIFMS, 2017-I2M-3-015).

\section{Authors' contribution}

Y.C. collected and analyzed the data and wrote the manuscript. J.Z., J.L., Q.W. and H.Y. collected and analyzed the data and revised the manuscript. W.Z., Y.Z., F.Z. and X.Z. designed the study, re-checked the diagnosis of all patients and revised the manuscript. S.Z. and Y.F. designed the study, analyzed the data and wrote the manuscript. All authors have read and approved the final manuscript. 
Acknowledgement

Not applicable.

\section{Abbreviations}

ANCA: antineutrophil cytoplasmic antibody

AVB: atrioventricular block

BVAS: Birmingham vasculitis activity score

CHF: chronic heart failure

CNS: central nervous system

CSS: Churg-Strauss syndrome

CT: computed tomography

CTA: computed tomography angiography

CTX: cyclophosphamide

DCG: dynamic electrocardiogram

ECG: electrocardiogram

EGPA: eosinophilic granulomatosis with polyangitis

ENT: ears, nose, and throat

ESR: erythrocyte sedimentation rate

FFS: Five Factor Score

GI: gastrointestinal

hsCRP: hypersensitive C-reactive protein

IgE: serum immunoglobulin $\mathrm{E}$

IQR: interquartile range

LAD: left anterior descending

LGE: late gadolinium enhancement;

LVEF: left ventricular ejection fraction 
MP: methylprednisolone

MRI: magnetic resonance imaging

NA: not available.

NT-proBNP: N-terminal prohormone of brain natriuretic peptide

PAH: pulmonary artery hypertension

Pred: prednisone

PVC: premature ventricular contraction

SD: standard deviation

SVT: supraventricular tachycardia

\section{References}

1. Churg J, Strauss L: Allergic granulomatosis, allergic angiitis, and periarteritis nodosa. Am J Pathol 1951, 27(2):277-301.

2. Jennette JC, Falk RJ, Bacon PA, Basu N, Cid MC, Ferrario F, Flores-Suarez LF, Gross WL, Guillevin L, Hagen EC et al: $\mathbf{2 0 1 2}$ revised International Chapel Hill Consensus Conference Nomenclature of Vasculitides. Arthritis and rheumatism 2013, 65(1):1-11.

3. Eustace JA, Nadasdy T, Choi M: Disease of the month. The Churg Strauss Syndrome. J Am Soc Nephrol 1999, 10(9):2048-2055.

4. Sinico RA, Di Toma L, Maggiore U, Bottero P, Radice A, Tosoni C, Grasselli C, Pavone L, Gregorini G, Monti S et al: Prevalence and clinical significance of antineutrophil cytoplasmic antibodies in Churg-Strauss syndrome. Arthritis and rheumatism 2005, 52(9):2926-2935.

5. Guillevin L, Cohen P, Gayraud M, Lhote F, Jarrousse B, Casassus P: Churg-Strauss syndrome. Clinical study and long-term follow-up of 96 patients. Medicine (Baltimore) 1999, 78(1):26-37.

6. Sable-Fourtassou R, Cohen P, Mahr A, Pagnoux C, Mouthon L, Jayne D, Blockmans D, Cordier JF, Delaval P, Puechal X et al: Antineutrophil cytoplasmic antibodies and the Churg-Strauss syndrome. Ann Intern Med 2005, 143(9):632-638.

7. Tervaert JW, Elema JD, Kallenberg CG: Clinical and histopathological association of 29kD-ANCA and MPOANCA. APMIS Supp/1990, 19:35.

8. Reid AJ, Harrison BD, Watts RA, Watkin SW, McCann BG, Scott DG: Churg-Strauss syndrome in a district hospital. QJM 1998, 91(3):219-229.

9. Dunogue B, Terrier B, Cohen P, Marmursztejn J, Legmann P, Mouthon L, Duboc D, Vignaux O, Guillevin L, French Vasculitis Study G: Impact of cardiac magnetic resonance imaging on eosinophilic granulomatosis with polyangiitis outcomes: A long-term retrospective study on $\mathbf{4 2}$ patients. Autoimmun Rev 2015, 14(9):774-780. 
10. Abu-Shakra M, Smythe H, Lewtas J, Badley E, Weber D, Keystone E: Outcome of polyarteritis nodosa and Churg-Strauss syndrome. An analysis of twenty-five patients. Arthritis and rheumatism 1994, 37(12):17981803.

11. Chumbley LC, Harrison EG, Jr., DeRemee RA: Allergic granulomatosis and angiitis (Churg-Strauss syndrome). Report and analysis of 30 cases. Mayo Clin Proc 1977, 52(8):477-484.

12. Gaskin G, Clutterbuck EJ, Pusey CD: Renal disease in the Churg-Strauss syndrome. Diagnosis, management and outcome. Contrib Nephrol 1991, 94:58-65.

13. Solans R, Bosch JA, Perez-Bocanegra C, Selva A, Huguet P, Alijotas J, Orriols R, Armadans L, Vilardell M: Churg-Strauss syndrome: outcome and long-term follow-up of 32 patients. Rheumatology (Oxford) 2001, 40(7):763-771.

14. Hazebroek MR, Kemna MJ, Schalla S, Sanders-van Wijk S, Gerretsen SC, Dennert R, Merken J, Kuznetsova T, Staessen JA, Brunner-La Rocca HP et al: Prevalence and prognostic relevance of cardiac involvement in ANCA-associated vasculitis: eosinophilic granulomatosis with polyangiitis and granulomatosis with polyangiitis. Int J Cardiol 2015, 199:170-179.

15. Vinit J, Bielefeld P, Muller G, Pfitzenmeyer P, Bonniaud P, Lorcerie B, Besancenot JF: Heart involvement in Churg-Strauss syndrome: retrospective study in French Burgundy population in past 10 years. Eur $\mathrm{J}$ Intern Med 2010, 21(4):341-346.

16. Lanham JG, Elkon KB, Pusey CD, Hughes GR: Systemic vasculitis with asthma and eosinophilia: a clinical approach to the Churg-Strauss syndrome. Medicine (Baltimore) 1984, 63(2):65-81.

17. Dennert RM, van Paassen P, Schalla S, Kuznetsova T, Alzand BS, Staessen JA, Velthuis S, Crijns HJ, Tervaert JW, Heymans S: Cardiac involvement in Churg-Strauss syndrome. Arthritis and rheumatism 2010, 62(2):627-634.

18. Haas C, Le Jeunne C, Choubrac P, Durand H, Hugues FC: [Churg-Strauss syndrome. Retrospective study of 20 cases]. Bull Acad Natl Med 2001, 185(6):1113-1130; discussion 1130-1113.

19. Guillevin L, Lhote F, Gayraud M, Cohen P, Jarrousse B, Lortholary O, Thibult N, Casassus P: Prognostic factors in polyarteritis nodosa and Churg-Strauss syndrome. A prospective study in $\mathbf{3 4 2}$ patients. Medicine (Baltimore) 1996, 75(1):17-28.

20. Guillevin L, Pagnoux C, Seror R, Mahr A, Mouthon L, Le Toumelin P, French Vasculitis Study G: The FiveFactor Score revisited: assessment of prognoses of systemic necrotizing vasculitides based on the French Vasculitis Study Group (FVSG) cohort. Medicine (Baltimore) 2011, 90(1):19-27.

21. Mahr A, Katsahian S, Varet H, Guillevin L, Hagen EC, Hoglund P, Merkel PA, Pagnoux C, Rasmussen N, Westman $\mathrm{K}$ et al: Revisiting the classification of clinical phenotypes of anti-neutrophil cytoplasmic antibody-associated vasculitis: a cluster analysis. Ann Rheum Dis 2013, 72(6):1003-1010.

22. Bourgarit A, Le Toumelin P, Pagnoux C, Cohen P, Mahr A, Le Guern V, Mouthon L, Guillevin L: Deaths occurring during the first year after treatment onset for polyarteritis nodosa, microscopic polyangiitis, and Churg-Strauss syndrome: a retrospective analysis of causes and factors predictive of mortality based on 595 patients. Medicine (Baltimore) 2005, 84(5):323-330.

23. Masi AT, Hunder GG, Lie JT, Michel BA, Bloch DA, Arend WP, Calabrese LH, Edworthy SM, Fauci AS, Leavitt RY: The American College of Rheumatology 1990 criteria for the classification of Churg-Strauss syndrome (allergic granulomatosis and angiitis). Arthritis Rheum 1990, 33(8):1094-1100. 
24. Luqmani RA, Bacon PA, Moots RJ, Janssen BA, Pall A, Emery P, Savage C, Adu D: Birmingham Vasculitis Activity Score (BVAS) in systemic necrotizing vasculitis. QJM 1994, 87(11):671-678.

25. Neumann T, Manger B, Schmid M, Kroegel C, Hansch A, Kaiser WA, Reinhardt D, Wolf G, Hein G, Mall G et al: Cardiac involvement in Churg-Strauss syndrome: impact of endomyocarditis. Medicine (Baltimore) 2009, 88(4):236-243.

26. Keogh KA, Specks U: Churg-Strauss syndrome: clinical presentation, antineutrophil cytoplasmic antibodies, and leukotriene receptor antagonists. (0002-9343 (Print)).

27. Miszalski-Jamka T, Szczeklik W, Sokołowska B, Karwat K, Belzak K, Mazur W, Kereiakes DJ, Musiał JJTIJoCl: Standard and feature tracking magnetic resonance evidence of myocardial involvement in Churg-Strauss syndrome and granulomatosis with polyangiitis (Wegener's) in patients with normal electrocardiograms and transthoracic echocardiography. 2013, 29(4):843-853.

28. Wassmuth R, Gobel U Fau - Natusch A, Natusch A Fau - Schneider W, Schneider W Fau - Kettritz R, Kettritz R Fau - Dietz R, Dietz R Fau - Luft FC, Luft Fc Fau - Schulz-Menger J, Schulz-Menger J: Cardiovascular magnetic resonance imaging detects cardiac involvement in Churg-Strauss syndrome. (1532-8414 (Electronic)).

29. Liu GY, Ventura IB, Achtar-Zadeh N, Elicker BM, Jones KD, Wolters PJ, Collard HR, Adegunsoye A, Strek ME, Ley B: Prevalence and Clinical Significance of Antineutrophil Cytoplasmic Antibodies in North American Patients With Idiopathic Pulmonary Fibrosis. Chest 2019.

30. Sinico RA, Di Toma L Fau - Maggiore U, Maggiore U Fau - Tosoni C, Tosoni C Fau - Bottero P, Bottero P Fau - Sabadini E, Sabadini E Fau - Giammarresi G, Giammarresi G Fau - Tumiati B, Tumiati B Fau - Gregorini G, Gregorini G Fau - Pesci A, Pesci A Fau - Monti S et al: Renal involvement in Churg-Strauss syndrome. (1523-6838 (Electronic)).

31. Saito Y, Okada S, Funabashi N, Kobayashi Y: ANCA-negative eosinophilic granulomatosis with polyangitis (EGPA) manifesting as a large intracardiac thrombus and glomerulonephritis with angionecrosis. LID 10.1136/bcr-2016-216520 [doi] LID - bcr2016216520 [pii]. (1757-790X (Electronic)).

32. Cohen P, Pagnoux C Fau - Mahr A, Mahr A Fau - Arene J-P, Arene Jp Fau - Mouthon L, Mouthon L Fau - Le Guern V, Le Guern V Fau - Andre M-H, Andre Mh Fau - Gayraud M, Gayraud M Fau - Jayne D, Jayne D Fau Blockmans D, Blockmans D Fau - Cordier J-F et al: Churg-Strauss syndrome with poor-prognosis factors: A prospective multicenter trial comparing glucocorticoids and six or twelve cyclophosphamide pulses in forty-eight patients. (0004-3591 (Print)).

33. Frustaci A, Gentiloni N Fau - Chimenti C, Chimenti C Fau - Natale L, Natale L Fau - Gasbarrini G, Gasbarrini G Fau - Maseri A, Maseri A: Necrotizing myocardial vasculitis in Churg-Strauss syndrome: clinicohistologic evaluation of steroids and immunosuppressive therapy. (0012-3692 (Print)). 